\title{
Traditional Bamboo Craft of Tripura: Its Diversification and Conservation
}

\author{
Animesh Sil $^{{ }^{*}}$, Smriti Rekha Sarkar ${ }^{2}$ and Archana Kumari ${ }^{1}$ \\ ${ }^{1}$ Department of Soil Science, SRI, Pusa, India \\ ${ }^{2}$ Department of Textile \& Apparel Designing, College of Community Science, \\ RPCAU, Pusa, Bihar-848125, India \\ *Corresponding author
}

\section{A B S T R A C T}

In India about 10 million hectare forest land is covered by bamboo. Tripura is one of the major bamboo producing states in India. Traditional bamboo craft provides

\section{Keywords}

Bamboo craft, Diversification, Conservation, Employment generation

Article Info

Accepted:

18 May 2020 Available Online: 10 June 2020 livelihood of the Tribal and other socially and economically backward classes of Tripura. The present study deals with traditional knowledge of bamboo utilization and their conservation. The study is based on literature survey and personal interview method at random with traditional bamboo artisans of Belonia subdivision and Agartala. Findings of the study reveal that in Tripura the skill of working with bamboo is extremely wide spread. Almost all artisans are belonging to below poverty line though they are excellent artisans. The craft sector is not the only user of bamboo; it is also used for food and medicine. As a result, the natural vegetation of bamboo is under the threat of depletion. Scientific management of the clump through selectively felling of mature culms each year is desirable for higher productivity of bamboo. Research and Development is needed for product line, quality control and preservation. Traditional methods of preservative treatment were practiced by the tribal bamboo craftsman.

\section{Introduction}

Topographically Tripura consists of a number of hill ranges, hillocks and hilly terrains interspersed with fields. Tripura is one of the major bamboo producing states in India.

Bamboo grows all across the state of Tripura covering over nearly 16-18 different species. Tripura bamboo handicrafts are considered to be among its best in the country for the exquisite designs, wide range of products and artistic appeal. Tripura being a small North East state, bamboo activity is spread over all the four districts of the state. However, it is thickly concentrated in South and West Tripura. Traditional method of utilization of bamboo provides direct and indirect economic benefit through employment generation of tribal and other socially and economically 
backward classes. There is a substantial market of the bamboo craft outside the state. The state supplies finished products to handicraft emporia in the metropolitan cities and handicraft fair, exhibition etc. in different parts of the country as well as abroad also.

The aim of the present study is to know about the existing traditional knowledge of bamboo utilization and conservation of bamboo craft and bamboo.

\section{Materials and Methods}

The present work is an attempt to focus into the traditional knowledge of bamboo craft and their management practices. The study is based on literature survey and personal interview method at random with traditional bamboo artisans of Belonia subdivision and Agartala. The technical persons of Tripura Bamboo Mission, Agartala were also interviewed for gathering required information's regarding innovative practices to promote bamboo articles. TBM is promoting bamboo craft for sustainable rural employment and conducting much training for the bamboo artisans on scientific management of bamboo for conservations. From secondary information, traditional utilization patter of bamboo in local sector was gathered. This information was also confirmed by the bamboo worker in the study area.

\section{Results and Discussion}

Besides traditional utilization, earlier paper and pulp industry consumed a big amount of bamboo in low price. But at present government is not encouraging the supply of bamboo for paper industry because in this case big business man is the profit gainer. Instead cottage industry for craft and other product making generates employment for the rural people of the state.
Bamboo shoots are used for food preparation. The species used for food preparation are Melocanna bacifera and Dendrocalamus asper mainly. Some species are used for medicinal purposes such Bambusa tulda used for tetanus and Dendrocalamus giganteus used for steroid drug and Schizostachyum capitatum used for stomach pain. Nowadays besides traditional utilization, bamboo is used in making incense stick and more than $60 \%$ of incense stick is supplied from Tripura to other parts of the country. Bambusa polymorpha and Melocanna baccifera are mainly used for incense stick.

Many species of bamboo are available in Tripura for diversified utilization (Table 1). Almost all species of bamboo are used by the artisans for craft/handicraft making in the study areas and other places of Tripura except Bambusa balcooa and Melocana baccifera. Melocana baccifera is a dominant species with over $80 \%$ coverage. It is primarily used for incense stick and domestic needs such as gate, fencing and construction.

\section{The bamboo arts and crafts of Tripura}

Among the traditional products there are many that have found substantial markets throughout the country. There is also large market for tribal products which includes carrying and storage baskets, fish traps, head gear, smoking pipes etc. The marketing of these products can be greatly enhanced if information relating to source, functions, significance in tribal life and interesting features of each item are provided along with the product.

Jamatia firewood basket: It is made of entirely from bamboo outer splits about $7 \mathrm{~mm}$ wide and $1.5 \mathrm{~mm}$ thick woven in plane weave base. This basket is used by the Jamatia tribes of Tripura for carrying firewood. 
Riang carrying basket: This is a closed-weave basket used by Riang tribe of Hilly Tripura to carry grains and for marketing. Basket is woven in twill pattern.

Tukri:The 'tukri' is a shallow basket used by the Bengalis of Tripura.

KarawalaTukri: It is used by Bengalis. It is identical to the 'tukri' with exception that four strong handles are attached to this basket. This tukriis used for carrying heavy items. This basket is made from split bamboo and handles (Kara) are made from split cane.

Laii: The 'laii' is a small bamboo basket used by Tripura Bengalis for washing rice.

SempaKhari: The 'Sempakhari' is a small basket shaped like a square based prism and used by Bengalis for storing small articles.

Date basket: This basket is used to store dates and is carried suspended from the waist band made of coarse bamboo inner splits.

Turi: The 'turi' is small semi-circular basket made from bamboo and used by Bengalis to keep puffed rice.

Sudha: This is a fish trap used by Jamatia tribe of Tripura.

Dulla: This is a fish basket with a square base and is woven in an open basket weave with 15 strips of bamboo, 7 in one direction and 8 at right angles to them.

Pathla: The 'pathla' from Tripura is a rain shield. The top cone has a base of 230 mm width and height of $110 \mathrm{~mm}$ and the circular shade that is angled slightly downwards has a diameter of $550 \mathrm{~mm}$.

Mudha: Mudha is a low stool of bamboo and split cane.

Chairs, Shelf (Tak) and other furniture: Beautiful furniture is made from cane and bamboo splits by weaving.

Riang Hookah: The Riang Tribe of Tripura uses a large hookah to smoke tobacco.
It is made of three parts. A clay bowl is connected by a short bamboo tube to a bamboo water container.

Bamboo root show pieces: Bamboo roots with stem are sculptures with different types of chisel for making beautiful eye catching artifacts used for interior decoration.

Rhizome artifacts: Bamboo rhizomes are given shape according to their form to make artifacts.

Bamboo Jewellery: Bamboo Jewellery is made from very fine bamboo split woven or knotted and binding is done by cane splits. This is a unique ecofriendly craft of the tiny state.

Bamboo mat, purse, bags, partition strips and half circle fan: All these products are made from fine bamboo sticks and cotton thread. Bamboo sticks are woven with cotton thread and decorated by painting on them. Nowadays bamboo sticks are dyed with direct and basic dyes to enhance its beauty and luster. Traditionally bamboo stem used for making handle of fan and flute is decorated by blowing flame in selected areas to create black printing effect.

Kula: Used for cleaning food grains, decoration and in ritual functions.

Other artifacts are lamp shades, wall pieces, mugs, woven hats, walking sticks and flute etc.

\section{Bamboo preservation}

The bamboo craftsman of Tripura depends on the bamboo craft since long back for their livelihood. Bamboo contains more starch and less toxic constituents. Due to this starch contents, they are more susceptible to insect, borer, fungi etc. To keep the bamboo free from fungi, insects, and borers and to maintain quality they are practicing some 
traditional method for preserving bamboo. Craftsmen informed that traditional methods of bamboo preservation are not permanent. Moreover some treatments may harm the quality of bamboo. So, chemical treatments are required for protecting bamboo and bamboo crafts for longer duration from borer, insects, termite and fungi.

The chemical treatments are given by steeping, diffusion and Boucherie process. The bamboo worker informed that bamboo should contain $50 \%$ moisture for effective result. Training on chemical treatment were organized by the Bamboo and Cane Development Institute and Tripura Bamboo Mission at Agartala and other parts of Tripura time to time for preserving bamboo for longer duration and maintaining its quality.

Table.1 Bamboo species used for arts and crafts

\begin{tabular}{|c|c|c|c|c|c|c|}
\hline Local Name & Botanical Name & Jewellery & Craft & Mats & Furniture & $\begin{array}{l}\text { Incense } \\
\text { stick }\end{array}$ \\
\hline Kanakaich & Thyrsostachs oliveri & & $\checkmark$ & & $\checkmark$ & \\
\hline Barak & Bambusa balcooa & & & & $\checkmark$ & $\checkmark$ \\
\hline Bom & Bambusa cucharensis & & $\checkmark$ & $\checkmark$ & $\checkmark$ & \\
\hline Mal/Makhla & Bambusa pallida & & $\checkmark$ & $\checkmark$ & & \\
\hline Paura & Bambusa polymorpha & & $\checkmark$ & & & \\
\hline Mirtinga & Bambusa tulda & $\checkmark$ & $\checkmark$ & $\checkmark$ & & \\
\hline Bari/jai & Bambusa vulgaris & $\checkmark$ & $\checkmark$ & & $\checkmark$ & \\
\hline Rupai & $\begin{array}{l}\text { Dendrocalamus } \\
\text { longispathus }\end{array}$ & $\checkmark$ & $\checkmark$ & $\checkmark$ & $\checkmark$ & \\
\hline Lathi Baans & Dendrocalamus strictus & & $\checkmark$ & & $\checkmark$ & \\
\hline Muli & Melocana baccifera & & & $\checkmark$ & & $\checkmark$ \\
\hline Dolu & Schizostachyum dullooa & & $\checkmark$ & & & \\
\hline Pencha Baans & Dendrocalamus hamitonii & & $\checkmark$ & & $\checkmark$ & \\
\hline
\end{tabular}

Table.2 Application of preservative treatment on bamboo by the bamboo craftsmen

\begin{tabular}{|c|c|c|}
\hline Sl. No. & Traditional method & Chemical treatment \\
\hline 1 & $\begin{array}{l}\text { Steeping green bamboo for } 21 / 2 \text { to } 3 \\
\text { months in clean water after } \\
\text { harvesting }\end{array}$ & $\begin{array}{l}\text { Bamboo is treated with:- Boric acid } \\
(1 \%)+\operatorname{Borax}(1.5 \%)=2.5 \% \\
\text { concentrate solution in water }\end{array}$ \\
\hline 2 & $\begin{array}{l}\text { By treating bamboo in smoke } \\
\text { chamber at } 120^{\circ}-150^{\circ} \mathrm{C}\end{array}$ & $\begin{array}{l}\text { CCB treatment:- Copper sulphate } \\
(3 \mathrm{~kg})+\text { Chrome }(6 \mathrm{~kg})+\text { Boron }(8 \mathrm{~kg}) \\
+183 \text { litre water }=8.5 \% \text { conc. } \text { solution }\end{array}$ \\
\hline 3 & By boiling bamboo in salted water & $\begin{array}{l}\text { Phenol + Copper sulphate } \\
(0.5 \%+0.5 \%)=1 \%\end{array}$ \\
\hline 4 & Applying Aldrin & \\
\hline 5 & $\begin{array}{l}\text { Treating dry bamboo with light } \\
\text { diesel oil }\end{array}$ & \\
\hline 6 & Hot and cold treatment with coal tar & \\
\hline
\end{tabular}




\section{Chart.I Diversified traditional utilization pattern of bamboo in Tripura}

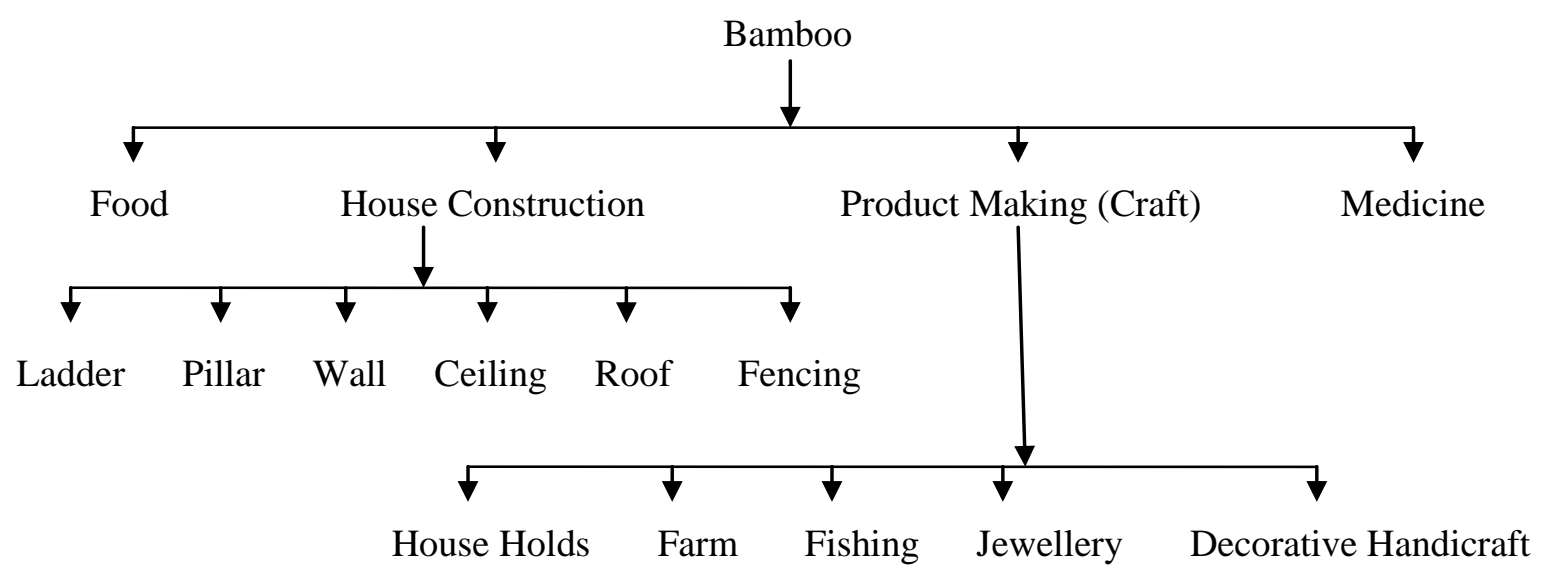

In conclusions, Tripura is a treasure house of vibrant tradition of bamboo craft worked upon by a large work force of Tribal and other backward communities who have kept the craft alive. This craft provides direct and indirect economic benefit through employment generation to the artisans. Nearly, 16-18 species of bamboo are found in Tripura, which are used as food, medicine, jewellery, craft, house construction, incense stick etc. More training to the craftsman is required for preserving bamboo and bamboo crafts.

Traditional knowledge of preservation method is not suitable for preserving bamboo for longer time. Some chemicals used for preservations are harmful to environment. Tripura government is encouraging bamboo craft industry through launching Tripura Bamboo Mission at Agartala. The Mission operationalized through private public partnership framework. The all India Handicrafts Board had established a Bamboo and Cane Development Institute, which has taken up research in the chemical treatment of bamboo.

\section{Recommendation}

Some suggestive measures are forwarded to adopt some policy measures for the conservation of bamboo vegetation and ecofriendly bamboo craft. Bamboo craft is the major source of developing rural economy of the state. This industry has a great export potential as well because greater acceptance of eco-products processed in ecological parameters is encouraging in world trade. Pricing policy, transportation, consumption of bamboo in all sectors needs to be solved with the policy maker. Technical research is needed to develop eco-friendly preservatives and scientific management of clump for higher productivity. New range of product line could be developed considering traditional knowledge for contemporary market maintaining quality of the products.

\section{References}

1. Nath, A.J., Das, G., Das, A.K., (2009). Traditional knowledge base in the management of village bamboos: A case study in Barak Valley, Assam, NorthEast India, Indian Journal of Traditional Knowledge, 8(2): 163-168.

2. Training manual of Tripura Bamboo Mission on bamboo plantation (2006).

3. Training manual of Tripura Bamboo Mission on bamboo preservation methods.

4. www.tripurabamboo.com. 


\section{How to cite this article:}

Animesh Sil, Smriti Rekha Sarkar and Archana Kumari. 2020. Traditional Bamboo Craft of Tripura: Its Diversification and Conservation. Int.J.Curr.Microbiol.App.Sci. 9(06): 1714-1719. doi: https://doi.org/10.20546/ijcmas.2020.906.212 